特 集 泌尿器科之腎 疾 患 ${ }^{* *}$

一一当科で行なった各種手術のうち，過去 20 年間の腎手術統計と， 過去 7 年間の入院患者手術統計について——

Renal Diseases in Urology

木 根 淵 清 志* 中 條 雅 生*

KIYoshi KINEBUCHI, M.D., \& MASAO NAKAJO, M.D.

近年各種検查技術，手術手技执よび化学療法の 発展に伴ない, 泌尿器科領域でも, 腎疾患に対し て以前の如き単なる腎別出術が主体であった姿か ら，漸次腎保存の方向に方針が変わりつつあり， この特集を機会に昭和 30 年から 49 年まで 20 年間の 当科に和ける腎手術の内容を中心として，最近の 手術の傾向を紹介する.

\section{入院 ·外来患者数亡手術件数}

昭和 30 年より昭和 49 年までの外来患者数，入院 患者数括よび手術件数を表 1 に示した.

年毎に徐々に増加の傾向にあり，昭和 44 年度か らでは年間 2400 3000名前後である.

入院患者数 2,924 名は外来患者の $7.3 \%$ である 昭和 38 年頃より, 約 10 年間は使用可能の病床数 がほとんど変わらなかったので概ね一定していた が，この 2 年間でやや増加している.

20 年間の全手術件数は 3,833 件で，外来患者数 の 9.6\%，年間平均手術件数は 191.7 件で，昭和 32 年頃より流とんど変わらないのはこれも使用可 能のベッド数の制限による.

昭和 44 年 1 月より昭和 50 年 10 月までの 6 年 10 カ 月間の外来，入院手術件数を表 2 に示す.

年間平均手術件数は 195.2 件でその内外来手術 の平均は $32.6 \%$, 入院手術が $67.4 \%$. 一般に入院 手術が少ない年度は外来手術が多くなっている.

* 順天堂大学医学部助手 (泌尿器科学講座)

Department of Urology, Juntenedo University, School of Medicine.

** 第195回順天堂医学会学術集会 (Nov., 15. 1975) [Dec., 17. 1975 受付)

\section{腎手術, 術式別手術件数}

腎手術について，術式別の手術件数を表 3 に示 す. 20 年間に和ける腎の手術件数は 602 件で，こ れは全手術 3,833 件の $15.7 \%$ である.

腎剔出術が 347 件で，全手術の $9.0 \%$ ，腎手術の $57.6 \%$ と最も多いが，昭和 41 年以後では腎剔出術

表 1 昭和 30 年 49 年 年度別外来 - 入院患者数 拉よび手術件数

\begin{tabular}{|c|c|c|c|c|}
\hline 年 & 度 & 外来患者数 & 入院患者数 & 手術件数 \\
\hline \multicolumn{2}{|c|}{ 昭和30年 } & (約) 1,100 & 145 & 57 \\
\hline & 1 & (約) 1,200 & 152 & 59 \\
\hline & 2 & 1,254 & 132 & 214 \\
\hline & 3 & 1,592 & 121 & 223 \\
\hline & 4 & 1,709 & 117 & 207 \\
\hline & 5 & 1,594 & 109 & 208 \\
\hline & 6 & 1,653 & 105 & 202 \\
\hline & 7 & 1,461 & 118 & 219 \\
\hline & 8 & 1,845 & 149 & 206 \\
\hline & 9 & 2,117 & 159 & 227 \\
\hline & 0 & 2,396 & 154 & 238 \\
\hline & 1 & 2,463 & 157 & 200 \\
\hline & 2 & 1,620 & 165 & 191 \\
\hline & 3 & 2,181 & 172 & 211 \\
\hline & 4 & 2,634 & 145 & 184 \\
\hline & 5 & 2,394 & 153 & 182 \\
\hline & 6 & 2,958 & 145 & 200 \\
\hline & 7 & 2,509 & 157 & 213 \\
\hline & 8 & 2,634 & 191 & 193 \\
\hline & 9 & 2,509 & 178 & 199 \\
\hline 合 & 計 & 39,823 & 2,924 & 3,833 \\
\hline
\end{tabular}


が減り，腎剔出術 120 例に対し，その他の手術が 148 件で，腎剔出術が $44.8 \%$ と逆転して減って抒 り, 特に最近はその傾向が強く, 雭性腫瘍を除 き，各種疾患に㧧いて，腎の保存的手術が增加し てきている.

次いで腎孟切石術が89例，腎手術の $14.8 \%$ ，腎 切石術 29 例， $4.8 \%$ ，腎部分切除術 5 例， $0.8 \%$, 腎 - 腎孟切石術 6 例， $1 \%$ ，腎孟形成術 24 例，

表 2 昭和 44 年〜昭和 50 年 10 月までの泌尿器科 外来 - 入院年度別手術件数

\begin{tabular}{|c|c|c|c|}
\hline 度 & 外来手術 & 入 院 & 合 \\
\hline 昭和 44 年 & 53 & 131 & 184 \\
\hline 45 & 46 & 136 & 182 \\
\hline 46 & 57 & 143 & 200 \\
\hline 47 & 85 & 128 & 213 \\
\hline 48 & 74 & 119 & 193 \\
\hline 49 & 67 & 132 & 199 \\
\hline $\begin{array}{c}50 \\
\text { (10月まで) }\end{array}$ & 70 & 146 & 216 \\
\hline 合計 & 452 & 935 & 1,387 \\
\hline 平均 & 63.7 & 131.5 & 195.2 \\
\hline
\end{tabular}

$3.9 \%$ ，腎瘻形成術 19 例， $3.1 \%$ ，腎固定術 50 例， $8.3 \%$.

以上が主なもので，腎結石についての腎保存的 手術が多い.

\section{腎剔出術 347 例について}

20 年間に於ける腎剔出術 347 例について 疾患別 に分類し表 4 に示す.

疾患数が 351 例と多いが，これは 1 症例で 2 疾 患以上を合併したものがあった為である。

腎結核：20年間で最も多く腎剔出術が行なわれ た疾患は腎結核で 127例，36.2\%である。

化学療法が発達した現在, 腎あるいは尿路の結 核は泌尿器科を受診する外来患者の数\%にすぎな くなり ${ }^{1)}$ ， なた腎剔出術以外の保存的な手術，即 ち尿路変更術，あるいは尿路形成術など手術方法 の改善により，当科でも昭和35年の 16例を頂点之 して漸減し，この 5 年間では 9 例しか行なわれて 扔らず，㛑剔出術が行なわれた他の疾患数と比べ ると16.4\%にすぎない，また，これらの症例もほ ぼ完全に尿路閉塞による腎機能の廃絶を認めた症 例である。

表 3 腎の手術 - 術式別手術件数（昭和 30 年〜昭和 49 年）

\begin{tabular}{|c|c|c|c|c|c|c|c|c|c|c|c|c|c|c|c|c|c|c|c|c|c|c|c|}
\hline $\begin{array}{l}\text { 年 度 } \\
\text { 術 式 } \\
\end{array}$ & 30 & 31 & 323 & 33 & 34 & 35 & 36 & 37 & 38 & 39 & 40 & 41 & 42 & 43 & 44 & 45 & 46 & 47 & 48 & 49 & 合計 & 率 $(\%)$ & $\begin{array}{l}3833 \\
\text { 全手術 } \\
\text { 飞対L }\end{array}$ \\
\hline 腎剔 出 術 & & 11 & 242 & 21 & & 32 & 23 & 21 & 22 & & 29 & 13 & 17 & 21 & 14 & 18 & 14 & 8 & 9 & 6 & 347 & 57.6 & 9.0 \\
\hline 警部分切除術 & & & & & & & 1 & & & 1 & & 1 & & & & 1 & & 1 & & & 5 & 0.8 & 0.1 \\
\hline 㛑苳 結 紮 & & & & & & & & & & & & & & & 1 & & & & & & 1 & 0.2 & \\
\hline 腎・腎貫切石術 & & & & & & & & & & & & & & & & & & & 4 & 2 & 6 & 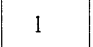 & 0.2 \\
\hline 腎石 切術 & 2 & & 1 & & & & 1 & 2 & 2 & 3 & 1 & 2 & 3 & 3 & & & 1 & 4 & 2 & 2 & 29 & .8 & 0.7 \\
\hline 腎盘切石術 & 1 & & 5 & 3 & 3 & 4 & 1 & 1 & 2 & 5 & 4 & 2 & 10 & 11 & 5 & 7 & 4 & 8 & 7 & 6 & 9 & 14.8 & 2.3 \\
\hline 腎孟形成術 & & & 1 & & & 1 & & & & 2 & 3 & 2 & & 5 & & 1 & 2 & 1 & 2 & 4 & 24 & 3. 9 & 0.6 \\
\hline 珡瘦形成術 & & & 2 & & 1 & & & & & 1 & 1 & 2 & & 1 & & 3 & 4 & & 2 & 2 & 19 & 3. 1 & 0.5 \\
\hline 瀷胞腎囊胞壁切除術 & & 2 & 1 & & & & & & & & 3 & 1 & 3 & & & & 1 & 1 & & & 12 & 2.0 & 0.3 \\
\hline 腎囊胞壁切除術 & & & & & & & & & & & & & & & 1 & & 1 & 2 & 1 & 1 & 6 & 1. & 0.2 \\
\hline 腎 固 定 術 & 1 & 5 & 5 & 4 & 5 & 4 & 4 & 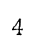 & 5 & 1 & 1 & & & 1 & 2 & 4 & 1 & 1 & & 2 & 50 & 8.3 & 1.3 \\
\hline 腎生検（開放性） & & & & & & & & & & 1 & & & & & & 2 & & & & & 3 & 0.5 & 0.1 \\
\hline 腎破裂縫合 & & & & & & & & & & & & & & & & 1 & & & & & 1 & 0.2 & \\
\hline 腎被膜剝離術 & & & 1 & & & & & & & & & & & & & & & & & & 1 & 0.2 & \\
\hline 試 験 切 開 & 1 & & 1 & & 1 & 1 & & & & & & 3 & 1 & & & & & & & 1 & 9 & 1.5 & 0.2 \\
\hline 合 & 12 & 18 & 412 & 28 & 25 & 42 & 30 & 2 & 3 & 36 & 42 & 26 & 34 & 42 & 23 & 37 & 28 & 26 & 27 & & 602 & 100 & 15.7 \\
\hline
\end{tabular}


表 4 昭和 30 年〜 49年 腎剔出術に招ける疾患別分類

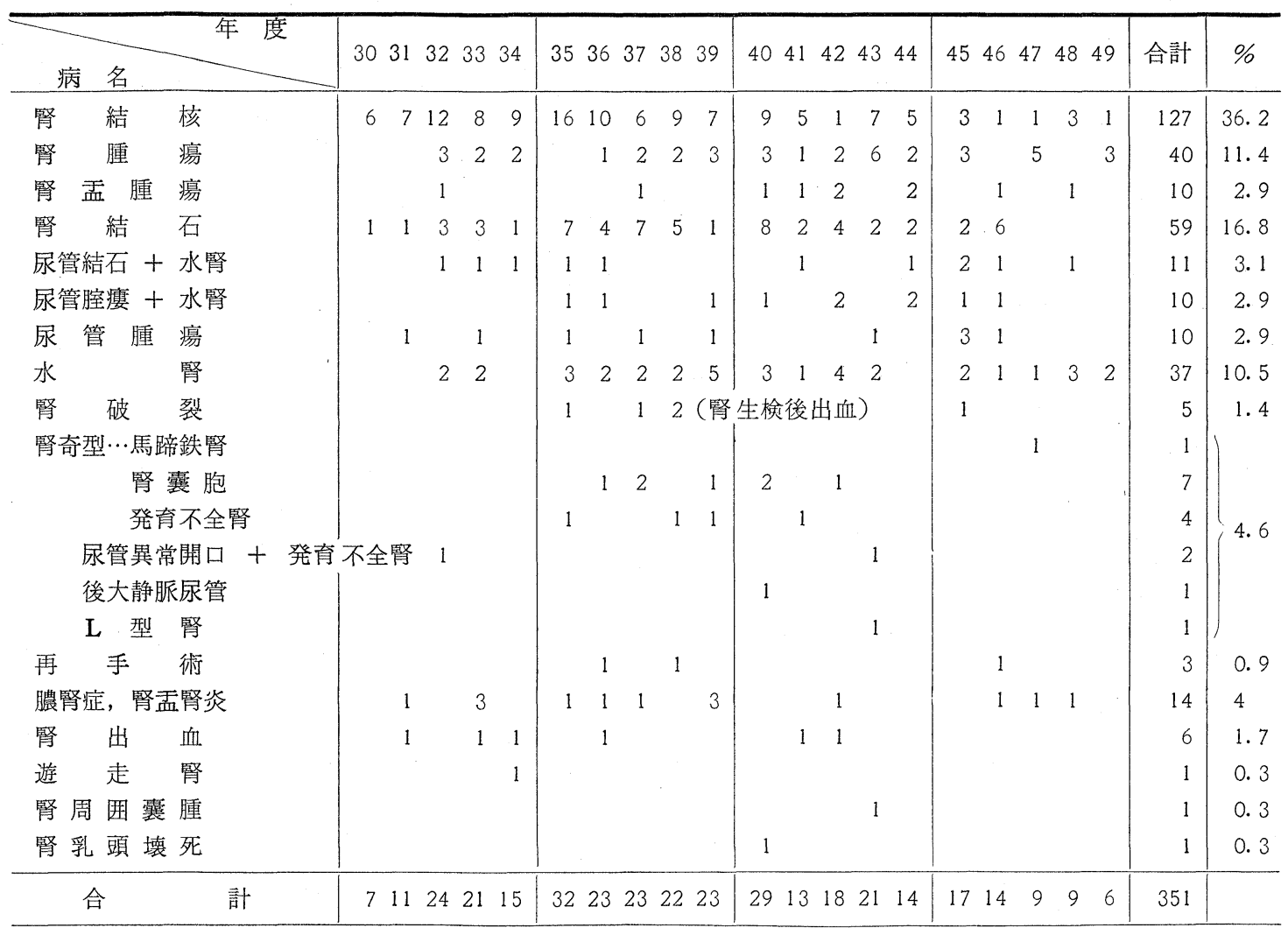

上部尿路結石：近年きわめて多く遭遇する疾患 で，上部尿路の結石があげられる.

尿路結石に対する保存的な治療法には腎機能を 保持という点で限界があり，手術的な処置を必要 とする場合が多く，また，腎結石に対する手術で は，腎実質に対する浸襲を減らすような方向を考 えねばならず，現在でも治療の面で多くの問題を 残している.

尿路結石の手術は泌尿器科で行なわれる最も多 い手術の 1 つで, その 1 つに腎結石の手術がある.

当科に於敄る 20 年間の腎結石に対する腎剔出術 は 59例，16.8\%である. 昭和41年以降はやはり漸 減の傾向にあり, 特に昭和 47 年以後の 3 年間は腎 剔出術はなく, 腎孟切石術, 腎切石術, 腎・腎孟 切石術のような腎保存の手術が増加し, 手術方法 の変更を示して和り, 手術術式, 手術材料(針付き カットグットなど）の改善, 化学療法の発達によ
る効果が大であると思われる.

腎腫瘍：腎結石の次に多い腎腫瘍についてみ る. 腎腫瘍は各臟器癌の $1 \sim 2 \%$ 程度で, 当科外 来患者の $0.1 \%$ ，入院患者の $1.2 \%$ にすぎないが， その $90 \%$ 以上，当科の症例では $95.8 \%$ は悪性腫瘍 であり，臨床的には重要な疾患である。もちろん 早期発見による腎剔出術が最良の方法で表 5 に示 す如く，当科では腎実質腫湟が 20 年間に51症例め り，40例 78.4\%で腎剔出術が行なわれ，8 例 21.6 \%が試験手術のみに終わっている.

更に, 腎腫瘍について当科の症例の内容を述べ ると, 表 6 の如く腎腫瘍の種類では腎癌が最も多 $<, 37$ 例, $72.6 \%$, Wilms 腫瘍 4 例, $7.8 \%$, 肉 3 例腫, $5.9 \%$, その他である.

年令分布では 40 代〜 70代が 32 例, $86.5 \%$ を占め ている.

治療は表 7 の如く腎剔が最も多く，その他術後 
の放射線療法, 一部手術前後の抗腫瘍剂の投与が 行なわれている。

水腎症：以上の腎結核，腎結石および腎腫瘍は 腎剔出術の三大疾患と言光るが，次に多いのは， 腎孟尿管移行部の狭窄のような先天性の疾患によ ると思われる水腎症，あるいは下部尿路の閉塞に よるものなど各種原因による水腎症 37例，10.5\% が上げられる，更に尿管結石による著明な水腎症 11例を加觉ると48例，13.7\%となる。

この水腎症も, 最近先天性疾患に対する早期の 診断が確立されるようになってきて拉り, 今後腎 孟形成術のような保存的な手術が多くなり腎剔の 症例は減少するものと思われる。

その他：膿腎症，腎孟腎炎 14例，4\%は尿管結 石, あるいは下部尿路の腫瘍性, 結核性, 他疾患 の術後などの閉塞, あるいは再発性の腎孟腎炎を 含んだものが大部分で，化学療法が無効であった 症例である。

次に腎孟腫瘍 10例， $2.9 \%$ ，尿管腫癔 10 例， 2.9 \%がある.

腎孟あるいは尿管腫瘍は，以前診断が困難な疾 患とされて和り，特に尿管腫瘍は1965年まで，本

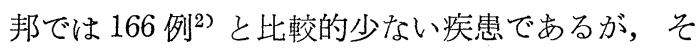
の後は報告例も多く, 当科では11例経験している.

尿管腫崵の術前診断は他の腫瘍に比較し, 術前
表 5 昭和 30 年 49 年 - 腎腫演入院患者数

\begin{tabular}{c|c|c|c|c}
\hline 年度 & 入院者数 & 腎腫瘍入院数 & 全手術数 & 腎剔数 \\
\hline 30 & 145 & 0 & 57 & 0 \\
31 & 152 & 0 & 59 & 0 \\
32 & 132 & 4 & 214 & 3 \\
33 & 121 & 2 & 223 & 2 \\
34 & 117 & 3 & 207 & 2 \\
35 & 109 & 1 & 208 & 0 \\
36 & 105 & 1 & 202 & 1 \\
37 & 118 & 2 & 219 & 2 \\
38 & 149 & 1 & 206 & 2 \\
39 & 159 & 3 & 227 & 3 \\
40 & 154 & 4 & 238 & 3 \\
41 & 157 & 3 & 200 & 1 \\
42 & 165 & 2 & 191 & 2 \\
43 & 172 & 6 & 211 & 6 \\
44 & 145 & 3 & 184 & 2 \\
45 & 153 & 3 & 182 & 3 \\
46 & 145 & 0 & 200 & 0 \\
47 & 157 & 10 & 213 & 5 \\
48 & 191 & 0 & 193 & 0 \\
49 & 178 & 3 & 199 & 3 \\
\hline 合計 & 2,924 & 51 & 3,833 & 40 \\
\hline & & & & \\
\hline
\end{tabular}

の診断適中率は $50 \%$ 以下と低く，また尿管壁の薄 さから周囲への浸潤が早く，また尿管の閉塞が早 期に起こり ${ }^{3)}$, 患側腎の機能の廃絶の為, 排泄性

表 6 昭和30年〜 49年・腎実質腫瘍の年令分布

\begin{tabular}{|c|c|c|c|c|c|c|c|c|c|c|c|c|c|}
\hline & \multirow{2}{*}{$\begin{array}{l}\text { 症 } \\
\text { 例 } \\
\text { 数 }\end{array}$} & \multicolumn{2}{|c|}{ 性 別 } & \multicolumn{2}{|c|}{ 患 側 } & \multirow{2}{*}{$0 \sim 9$} & \multirow{2}{*}{$10 \sim 19$} & \multirow{2}{*}{$20 \sim 29$} & \multirow{2}{*}{$30 \sim 39$} & \multirow{2}{*}{$40 \sim 49$} & \multirow{2}{*}{$50 \sim 59$} & \multirow{2}{*}{$60 \sim 69$} & \multirow{2}{*}{ 70以上 } \\
\hline & & $\hat{\delta}$ & 우 & 右 & 左 & & & & & & & & \\
\hline 腎 & 37 & 22 & 15 & 17 & 20 & & & 2 & 2 & 9 & 12 & 11 & 1 \\
\hline Wilms 腫 瘍 & 4 & 1 & 3 & 3 & 1 & 4 & & & & & & & \\
\hline 肉 & 3 & 1 & 2 & & 3 & & & & & & & 2 & 1 \\
\hline 良性 & 2 & & 2 & 1 & 1 & & & & 1 & 1 & & & \\
\hline 悪性 & 1 & 1 & & & 1 & & & 1 & & & & & \\
\hline 血管線維腫 & 1 & 1 & & & 1 & & & & & & & & \\
\hline 不 & 3 & 1 & 2 & 3 & & & & & & & 1 & 2 & \\
\hline 計 & 51 & 27 & 24 & 24 & 27 & 4 & 0 & 3 & 3 & 10 & 13 & 15 & 2 \\
\hline
\end{tabular}


表 7 昭和30年〜 49年・腎実質腫瘍種類による 治療法

\begin{tabular}{|c|c|c|c|c|}
\hline 腫瘍種類 & 腎 晨 & ||試験手術 & 放射線療法 & 化学療法 \\
\hline 癌 & 29 & 7 & 22 & 11 \\
\hline Wilms 腫 瘍 & 4 & & 3 & 3 \\
\hline 腫 & 3 & & 2 & 1 \\
\hline 過 誤 腫 & 3 & & & \\
\hline 血管腺 維 種 & 1 & & & \\
\hline 明 & & 1 & 4 & 1 \\
\hline 合 & 40 & 8 & 31 & 16 \\
\hline
\end{tabular}

腎孟撮影のみによる搒断は困難な場合が多く，本 症発見の為には特に注意深い泌尿器科的な検査, とくに尿管カテーテル法なぞが大切である.

これら腎孟めるいは尿管腫瘍に対しては普通腎 剔出術のみではなく，尿管拉よび膀胱部分切除術 が併用されている。
他に 腎奇形に対する腎剔出術が 16例，4.6\% あ るが，これらは水腎，䐌結石むるいは腎孟腎炎な ぞの合併症を全例含んでいた為剔出術を行なわ称 ばならなかった症例である。

以上腎剔出術 351 例について疾患別に概述した が，ここでまとめてみる。過去 10年前後に目立っ てきた事は結核腎の腎剔出術の減少と, 腎結石に 対する各種の腎保存的手術が增加した事である.

腎切石術, 腎孟切石術, 腎・腎孟切石術, あるい は時に腎結石を含む水腎症の腎孟形成術など 148 例は手術手技の向上，化学療法の発達によるもの が大であり，今後も增加する手術である.

一方悪性腫湟に対する手術件数は，昭和39年頃 よりほとんど変わらず，手術内容が一定の型に決 昰っている事を示し, 今後他の放射線療法, 化学療 法あるいは免疫学的な治療の発達を期待したい。

20年間の腎剔出術が行なわれた症例の年令分布

表 8 昭和30年〜 49年に括ける㛑剔出術の年令

\begin{tabular}{|c|c|c|c|c|c|c|c|c|c|c|c|c|c|c|c|c|c|c|c|c|c|c|}
\hline & & 30 & 31 & 32 & 33 & 34 & 35 & 36 & 37 & 38 & 39 & 40 & 41 & 42 & 43 & 44 & 45 & 46 & 47 & 48 & 49 & 合 計 \\
\hline $0 \sim 10$ & $\begin{array}{l}\text { 男 } \\
\text { 女 }\end{array}$ & & & & & 1 & 2 & & 1 & & 2 & & & 1 & & & & & 1 & & $\begin{array}{l}1 \\
1\end{array}$ & $\begin{array}{l}7 \\
3\end{array}$ \\
\hline $11 \sim 20$ & $\begin{array}{l}\text { 男 } \\
\text { 女 }\end{array}$ & 1 & & 1 & 1 & 1 & 1 & $\begin{array}{l}3 \\
2\end{array}$ & & 2 & & 1 & 1 & & & & 1 & & & 2 & & $\begin{array}{r}10 \\
8\end{array}$ \\
\hline $21 \sim 30$ & $\begin{array}{l}\text { 男 } \\
\text { 女 }\end{array}$ & $\begin{array}{l}2 \\
1\end{array}$ & $\begin{array}{l}1 \\
1\end{array}$ & $\begin{array}{l}6 \\
5\end{array}$ & 1 & $\begin{array}{l}2 \\
1\end{array}$ & 6 & 6 & 4 & $\begin{array}{l}2 \\
2\end{array}$ & $\begin{array}{l}2 \\
1\end{array}$ & $\begin{array}{l}4 \\
1\end{array}$ & 1 & $\begin{array}{l}1 \\
2\end{array}$ & $\begin{array}{l}2 \\
2\end{array}$ & $\begin{array}{l}1 \\
1\end{array}$ & $\begin{array}{l}1 \\
1\end{array}$ & 2 & 1 & 2 & & $\begin{array}{l}38 \\
30\end{array}$ \\
\hline $31 \sim 40$ & $\begin{array}{l}\text { 男 } \\
\text { 女 }\end{array}$ & 2 & $\begin{array}{l}1 \\
1\end{array}$ & $\begin{array}{l}2 \\
3\end{array}$ & $\begin{array}{l}1 \\
4\end{array}$ & $\begin{array}{l}2 \\
2\end{array}$ & 3 & $\begin{array}{l}2 \\
1\end{array}$ & $\begin{array}{l}3 \\
3\end{array}$ & $\begin{array}{l}1 \\
3\end{array}$ & $\begin{array}{l}2 \\
3\end{array}$ & $\begin{array}{l}1 \\
4\end{array}$ & $\begin{array}{l}1 \\
2\end{array}$ & $\begin{array}{l}1 \\
1\end{array}$ & $\begin{array}{l}1 \\
1\end{array}$ & $\begin{array}{l}2 \\
1\end{array}$ & $\begin{array}{l}3 \\
4\end{array}$ & $\begin{array}{l}1 \\
1\end{array}$ & 1 & 1 & & $\begin{array}{l}34 \\
39\end{array}$ \\
\hline $41 \sim 50$ & $\begin{array}{l}\text { 男 } \\
\text { 女 }\end{array}$ & & $\begin{array}{l}1 \\
2\end{array}$ & 1 & $\begin{array}{l}4 \\
1\end{array}$ & 2 & 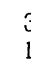 & $\begin{array}{l}3 \\
3\end{array}$ & $\begin{array}{l}2 \\
2\end{array}$ & $\begin{array}{l}2 \\
3\end{array}$ & $\begin{array}{l}4 \\
1\end{array}$ & $\begin{array}{l}2 \\
2\end{array}$ & $\begin{array}{l}2 \\
1\end{array}$ & $\begin{array}{l}2 \\
3\end{array}$ & $\begin{array}{l}3 \\
2\end{array}$ & $\begin{array}{l}1 \\
4\end{array}$ & $\begin{array}{l}2 \\
3\end{array}$ & & $\begin{array}{l}2 \\
1\end{array}$ & $\begin{array}{l}1 \\
1\end{array}$ & $\begin{array}{l}2 \\
1\end{array}$ & $\begin{array}{l}38 \\
32\end{array}$ \\
\hline $51 \sim 60$ & $\begin{array}{l}\text { 男 } \\
\text { 女 }\end{array}$ & 1 & 2 & $\begin{array}{l}2 \\
1\end{array}$ & 1 & $\begin{array}{l}1 \\
1\end{array}$ & 1 & $\begin{array}{l}1 \\
2\end{array}$ & $\begin{array}{l}3 \\
3\end{array}$ & $\begin{array}{l}3 \\
4\end{array}$ & $\begin{array}{l}1 \\
5\end{array}$ & $\begin{array}{l}2 \\
6\end{array}$ & $\begin{array}{l}2 \\
2\end{array}$ & $\begin{array}{l}1 \\
1\end{array}$ & $\begin{array}{l}2 \\
4\end{array}$ & 2 & 2 & $\begin{array}{l}3 \\
2\end{array}$ & 2 & 1 & & $\begin{array}{l}35 \\
33\end{array}$ \\
\hline $61 \sim 70$ & $\begin{array}{l}\text { 男 } \\
\text { 女 }\end{array}$ & & 2 & $\frac{1}{1}$ & 4 & $\begin{array}{l}1 \\
1\end{array}$ & 1 & & & & & $\begin{array}{l}3 \\
2\end{array}$ & & 1 & $\begin{array}{l}1 \\
1\end{array}$ & & 1 & $\begin{array}{l}2 \\
1\end{array}$ & 2 & 1 & & $\begin{array}{r}20 \\
6\end{array}$ \\
\hline $71 \sim 80$ & $\begin{array}{l}\text { 男 } \\
\text { 女 }\end{array}$ & & & 1 & & & & 1 & & & 1 & 1 & & 2 & 2 & 1 & & 1 & & & $\begin{array}{l}1 \\
1\end{array}$ & $\begin{array}{l}5 \\
7\end{array}$ \\
\hline $81 \sim$ & $\begin{array}{l}\text { 男 } \\
\text { 女 }\end{array}$ & & & & & & & & & & & & 1 & & & & & & & & & 1 \\
\hline 小 計 & $\begin{array}{l}\text { 男 } \\
\text { 女 }\end{array}$ & $\begin{array}{l}3 \\
4\end{array}$ & $\begin{array}{l}7 \\
4\end{array}$ & $\begin{array}{l}12 \\
12\end{array}$ & $\begin{array}{r}14 \\
7\end{array}$ & $\begin{array}{l}9 \\
6\end{array}$ & $\begin{array}{l}21 \\
10\end{array}$ & $\begin{array}{r}9 \\
14\end{array}$ & $\begin{array}{r}12 \\
9\end{array}$ & $\begin{array}{l}10 \\
12\end{array}$ & $\begin{array}{l}12 \\
10\end{array}$ & $\begin{array}{l}14 \\
15\end{array}$ & $\begin{array}{l}7 \\
6\end{array}$ & $\begin{array}{l}7 \\
9\end{array}$ & $\begin{array}{r}9 \\
12\end{array}$ & $\begin{array}{l}7 \\
6\end{array}$ & $\begin{array}{r}10 \\
8\end{array}$ & $\begin{array}{l}8 \\
5\end{array}$ & $\begin{array}{l}8 \\
2\end{array}$ & $\begin{array}{l}6 \\
3\end{array}$ & $\begin{array}{l}4 \\
3\end{array}$ & $\begin{array}{l}189 \\
157\end{array}$ \\
\hline 合 & 計 & 7 & 11 & 24 & 21 & 15 & 31 & 23 & 21 & 22 & 22 & 29 & 13 & 16 & 21 & 13 & 18 & 13 & 10 & 9 & 7 & 346 \\
\hline
\end{tabular}


を表 8 に示す. 昭和 30 年前半に和忛る 20 才〜30才 代の手術の大部分は腎結核であり, 昭和 40 年代後 半の 40 才 50 才代の手術は腫瘍性疾患の割合が増 加した事を示す.

\section{腎以外の手術例}

以上 20 年間の当科に和ける腎手術の統計を示し
たが，次に最近 7 年間，昭和 44 年 1 月より昭和 50 年10月までに行なわれた腎以外の入院患者の全手 術を表に示す。

尿管の手術（表 9）190例

尿管切石術 127 例は, 7 年間の全手術件数 1,387 件に対して $9.2 \%$ で，前立腺の手術についで最も 多小.

表 9 尿管 の 手術

\begin{tabular}{|c|c|c|c|c|c|c|c|c|c|c|c|c|c|c|c|c|c|}
\hline 年 度 & \multicolumn{2}{|c|}{44} & \multicolumn{2}{|c|}{45} & \multicolumn{2}{|c|}{46} & \multicolumn{2}{|c|}{47} & \multicolumn{2}{|c|}{48} & \multicolumn{2}{|c|}{49} & \multicolumn{2}{|c|}{50} & \multicolumn{2}{|c|}{ 合 計 } & \multirow{2}{*}{$\begin{array}{ll}\text { 男 女 } \\
\text { 総 計 }\end{array}$} \\
\hline 術式名 性 別 & 男 & 女 & 男 & 女 & 男 & 女 & 男 & 女 & 男 & 女 & 男 & 女 & 男 & 女 & 男 & 女 & \\
\hline 尿 管 切 石 術 & 8 & 2 & 9 & 5 & 9 & 11 & 11 & 12 & 16 & 11 & 13 & 4 & 8 & 8 & 74 & 53 & 127 \\
\hline 尿 管 切 除 術 & 0 & 1 & 1 & 1 & 1 & 1 & 0 & 0 & 0 & 0 & 0 & 0 & 0 & 0 & 2 & 3 & 5 \\
\hline 尿管膀胱新吻 合術 & 1 & 1 & 0 & 2 & 1 & 0 & 3 & 2 & 1 & 1 & 2 & 1 & 3 & 1 & 11 & 8 & 19 \\
\hline 尿 管 瘻 設 置 術 & 3 & 2 & 1 & 6 & 0 & 1 & 1 & 1 & 0 & 0 & 4 & 2 & 4 & 0 & 13 & 12 & 25 \\
\hline 尿 管 腸 吻 合 術 & 1 & 0 & 0 & 2 & 0 & 0 & 1 & 0 & 0 & 0 & 0 & 0 & 2 & 0 & 4 & 2 & 6 \\
\hline 尿管端々吻合術 & 0 & 1 & 0 & 0 & 0 & 0 & 0 & 0 & 0 & 0 & 0 & 0 & 0 & 0 & 0 & 1 & 1 \\
\hline 尿 管 形 成 術 & 0 & 0 & 1 & 0 & 0 & 0 & 0 & 0 & 0 & 0 & 0 & 0 & 0 & 0 & 1 & 0 & 1 \\
\hline 尿管カテーテル留置 & 0 & 1 & 0 & 0 & 0 & 0 & 0 & 0 & 0 & 0 & 1 & 0 & 1 & 0 & 2 & 1 & 3 \\
\hline バスケット・カテーテル & 0 & 0 & 0 & 0 & 1 & 0 & 0 & 0 & 0 & 0 & 0 & 0 & 0 & 1 & 1 & 1 & 2 \\
\hline 尿 管 結 紮 術 & 0 & 0 & 0 & 0 & 0 & 0 & 0 & 0 & 0 & 0 & 0 & 0 & 0 & 1 & 0 & 1 & 1 \\
\hline
\end{tabular}

表 10 膀胱 の手 術

\begin{tabular}{|c|c|c|c|c|c|c|c|c|c|c|c|c|c|c|c|c|c|}
\hline 年 ${ }^{\text {度 }}$ & 4 & 4 & & & 4 & & & & & & & & & & 合 & 計 & \\
\hline 術式名性別 & 男 & 女 & 男 & 女 & 男 & 女 & 男 & 女 & 男 & 女 & 男 & 女 & 男 & 女 & 男 & 女 & \\
\hline 膀胱高位切開術 & 11 & 4 & 3 & 1 & 10 & 3 & 4 & 4 & 14 & 0 & 11 & 1 & 9 & 2 & 62 & 15 & 77 \\
\hline U. & 8 & 1 & 4 & 0 & 3 & 1 & 5 & 2 & 3 & 3 & 6 & 3 & 7 & 2 & 36 & 12 & 48 \\
\hline 膀胱部分切 除 術 & 3 & 2 & 4 & 2 & 2 & 1 & 7 & 0 & 2 & 0 & 4 & 1 & 2 & 0 & 24 & 6. & 30 \\
\hline 経尿道的異物摘出術 & 1 & 1 & 1 & 1 & 0 & 0 & 0 & 0 & 0 & 1 & 0 & 0 & 3 & 0 & 5 & 3 & 8 \\
\hline 膀 胱 瘦 閉 鎖 術 & 0 & 0 & 0 & 2 & 0 & 1 & 1 & 0 & 1 & 0 & 0 & 0 & 1 & 2 & 3 & 5 & 8 \\
\hline 膀 胱 瘦 設 置 術 & 2 & 0 & 0 & 0 & 0 & 0 & 1 & 0 & 0 & 0 & 3 & 0 & 0 & 0 & 6 & 0 & 6 \\
\hline 尿 管 口 切 開 術 & 0 & 0 & 0 & 0 & 2 & 0 & 1 & 0 & 1 & 0 & 0 & 0 & 1 & 0 & 5 & 0 & 5 \\
\hline 膀 胱 全 摘 術 & 1 & 0 & 0 & 0 & 0 & 0 & 0 & 0 & 0 & 0 & 0 & 0 & 2 & 0 & 3 & 0 & 3 \\
\hline 膀胱憩室 切除術 & 0 & 0 & 0 & 0 & 1 & 0 & 0 & 0 & 0 & 0 & 1 & 0 & 1 & 0 & 3 & 0 & 3 \\
\hline 尿管瘤切除術 & 0 & 1 & 0 & 0 & 0 & 0 & 0 & 0 & 0 & 0 & 0 & 1 & 0 & 0 & 0 & 2 & 2 \\
\hline 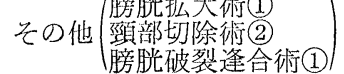 & 0 & 0 & 0 & 0 & 2 & 0 & 1 & 0 & 0 & 0 & 1 & 0 & 0 & 0 & 4 & 0 & 4 \\
\hline
\end{tabular}


表 11 前立腺の手術

\begin{tabular}{l|r|r|r|r|r|r|r|r}
\hline 術式名 \年度 & 44 & 45 & 46 & 47 & 48 & 49 & 50 & 計 \\
\hline 前立腺凍結術 & 16 & 19 & 14 & 12 & 6 & 18 & 11 & 96 \\
前立腺摘除術 & 8 & 8 & 14 & 7 & 11 & 4 & 10 & 62 \\
\hline
\end{tabular}

膀胱の手術（表10）194例

膀胱高位切開 77例, $5.6 \%$ が多く，これは主に 膀胱腫瘍めるいは膀胱結石に対して行なわれたも のである.

内視鏡的膀胱腫瘍切除術 (T. U. R.) 48例, 3.5 $\%$, 膀胱部分切除術 30 例, $2.2 \%$ は膀胱腫崵に対 して行なわれて和り，特に T.U.R.は今後増加す ると思われる。

前立腺の手術（表11）158例，11.4\%

前立腺疾患は泌尿器科比打最子多い疾患の 1 つで, 今後平均寿命の延長, 老人医療の完備に より更に増加するものと思われる。

当科では独自に考案, 開発した前立腺凍結装置 により，最近 7 年間に 96 例の前立腺肥大症, 前立 腺癌，膀胱頸部硬化症に対する手術を行なって和
り，良好な成績を得ている4).

陰荃・尿道の手術（表12）79例

尿道形成術 21 例 $1.6 \%$ 主に小児の尿道下裂に 対して行なった.

陰囊内藏器の手術（表13）162例

辡丸高位切除術 29例，2.1\% は囯丸腫瘍怙よび その疑いが持たれた症例に対して行なわれたもの である。

副腎の手術（表14）21例

副腎の手術は, 昭和 33 年より昭和 49 年まで 17 年 間の統計を示した。

クッシング症候群10例，腺腫祦よび過形成が各 5 例で最も多い。次いでアルドステロン症 6 例で める。

以上をなとめると，当科で行なわれた最も多い 手術は前立腺剔出術 $11.4 \%$, 尿管切石術 $9.2 \%$ て , 膀胱高位切開が次に多く $5.6 \%$, 腎剔出術 $5.0 \%$,

T.U.R. 3.5\%，単純除辠術 $2.4 \%$ ，睪丸固定術 $2.3 \%$, 膀胱部分切除術 $2.2 \%$, 高位除悬術 $2.1 \%$, 尿管瘦設置術 $1.8 \%$ などがある。

表 12 院蓡・尿道の手術

\begin{tabular}{|c|c|c|c|c|c|c|c|c|c|c|c|c|c|c|c|c|c|}
\hline 年 度 & & & 4 & & 4 & & 4 & & 4 & & 4 & & 5 & & 合 & 計 & \\
\hline 術式名性 別 & 男 & 女 & 男 & 女 & 男 & 女 & 男 & 女 & 男 & 女 & 男 & 女 & 男 & 女 & 男 & 女 & 総 計 \\
\hline 尿道形成 術 & 8 & 0 & 3 & 0 & 1 & 0 & 2 & 0 & 0 & 0 & 2 & 0 & 5 & 0 & 21 & 0 & 21 \\
\hline 環 状 切 除 術 & 0 & 0 & 2 & 0 & 4 & 0 & 1 & 0 & 0 & 0 & 3 & 0 & 3 & 0 & 13 & 0 & 13 \\
\hline 尿道 癗 設 置 術 & 3 & 0 & 1 & 0 & 0 & 0 & 0 & 0 & 0 & 0 & 0 & 0 & 2 & 0 & 6 & 0 & 6 \\
\hline 尿 道 脱 根 治 術 & 0 & 1 & 0 & 1 & 0 & 2 & 0 & 2 & 0 & 0 & 0 & 0 & 0 & 0 & 0 & 6 & 6 \\
\hline 陰 茎 切 断 術 & 2 & 0 & 0 & 0 & 0 & 0 & 1 & 0 & 0 & 0 & 1 & 0 & 1 & 0 & 5 & 0 & 5 \\
\hline 尿 道 瘻 閉 鎖 術 & 1 & 0 & 0 & 0 & 0 & 0 & 0 & 0 & 2 & 0 & 0 & 0 & 2 & 0 & 5 & 0 & 5 \\
\hline 尿道周囲膿瘍切開術 & 0 & 0 & 0 & 0 & 0 & 0 & 0 & 0 & 2 & 0 & 2 & 0 & 1 & 0 & 5 & 0 & 5 \\
\hline 尿道カルンケル 根治術 & 0 & 0 & 0 & 0 & 0 & 3 & 0 & 0 & 0 & 0 & 0 & 1 & 0 & 0 & 0 & 4 & 4 \\
\hline 尿道端々吻 合 術 & 0 & 0 & 0 & 0 & 0 & 0 & 3 & 0 & 0 & 0 & 0 & 0 & 0 & 0 & 3 & 0 & 3 \\
\hline 背 面 切 開 術 & 0 & 0 & 0 & 0 & 1 & 0 & 0 & 0 & 0 & 0 & 1 & 0 & 0 & 0 & 2 & 0 & 2 \\
\hline 尿 道 結 石 摘 除 術 & 0 & 0 & 0 & 0 & 0 & 0 & 1 & 0 & 0 & 0 & 0 & 0 & 1 & 0 & 2 & 0 & 2 \\
\hline そ の & 1 & 1 & 0 & 0 & 2 & 0 & 0 & 0 & 2 & 0 & 0 & 1 & 0 & 0 & 5 & 2 & 7 \\
\hline
\end{tabular}


結 語

昭和 30 年より昭和 49 年まで， 20 年間の当科飞お ける腎の手術 602 例について報告し，合わせて昭 和 44 年 1 月より 昭和 50 年 10 月までに行なわれた腎 以外の手術 1,387 例について統計を報告し，最近 の手術傾向について若干の考察を行なった。
文献

1) 黒川一男: 泌尿器科治療学, p. 252, 1970.

2) 北山太一, 他：泌尿紀要, 13, 40, 1967.

3 ) 野中 博 : 順天堂医学, 18, 40, 1972.

4) 野中 博, 高橋博元 : 臨泌, 27, 719, 1973.

表 13 陰囊内臟器の手術

\begin{tabular}{|c|c|c|c|c|c|c|c|c|}
\hline $\begin{array}{ll} & \text { 年 }{ }^{\prime} \text { 度 } \\
\text { 術式名 }\end{array}$ & 44 & 45 & 46 & 47 & 48 & 49 & 50 & 合 計 \\
\hline 䛭 丸 摘 除 術 & 4 & 6 & 2 & 5 & 4 & 7 & 5 & 33 \\
\hline 鋅 丸 固 定 術 & 4 & 2 & 4 & 7 & 6 & 4 & 5 & 32 \\
\hline 辡丸高位切除術 & 5 & 5 & 7 & 3 & 6 & 3 & 0 & 29 \\
\hline 陰孁水腫根治術 & 3 & 2 & 2 & 2 & 3 & 3 & 8 & 23 \\
\hline 副 擘 丸 摘 除 術 & 5 & 2 & 7 & 0 & 1 & 0 & 3 & 18 \\
\hline ヘルニア 根治術 & 0 & 2 & 0 & 1 & 2 & 1 & 1 & 7 \\
\hline 停留蔁丸試験切開術 & 1 & 1 & 2 & 0 & 0 & 1 & 0 & 5 \\
\hline 精 液 瘤 根 治 術 & 1 & 0 & 0 & 0 & 0 & 1 & 1 & 3 \\
\hline 陰虽内血腫除去術 & 1 & 0 & 0 & 1 & 0 & 0 & 1 & 3 \\
\hline 精索 水腫根治 術 & 0 & 0 & 1 & 0 & 0 & 0 & 1 & 2 \\
\hline 副金丸精管再吻合術 & 0 & 0 & 2 & 0 & 0 & 0 & 0 & 2 \\
\hline 他 & 0 & 0 & 2 & 0 & 0 & 2 & 1 & 5 \\
\hline
\end{tabular}

表 14 副堅 の手 術

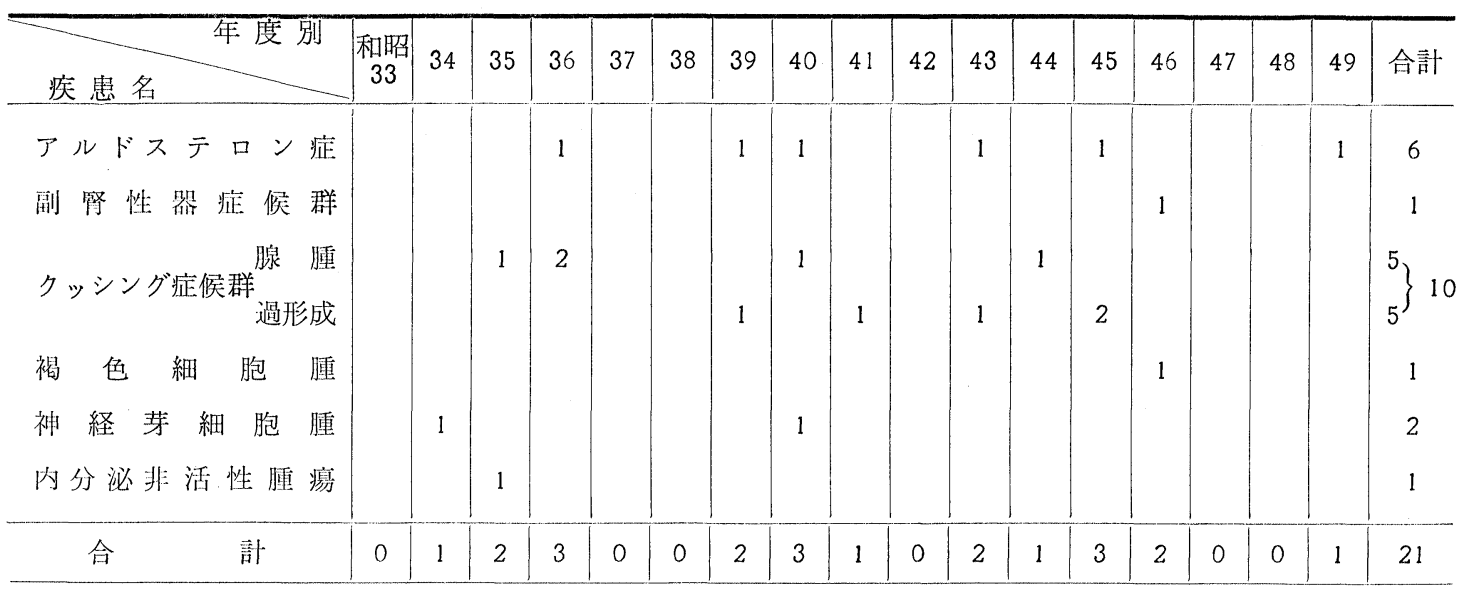

